\title{
A Critical Review on Whether the Use of a Teaching Practicum Observation Form Promotes Learner-Centred Approaches: A Case of Mzuzu University Teaching Practicum
}

\author{
Christopher Mpewe \\ Department of Teaching, Learning and Curriculum Studies, Mzuzu University, Malawi
}

\begin{abstract}
How to cite this paper: Mpewe, C. (2018) A Critical Review on Whether the Use of a Teaching Practicum Observation Form Promotes Learner-Centred Approaches: A Case of Mzuzu University Teaching Practicum. The Educational Review, USA, 3(1), 1-15. http://dx.doi.org/10.26855/er.2019.01.001
\end{abstract}

Corresponding author: Christopher Mpewe, Lecturer in Mathematics and Mathematics methodology, Department of Teaching, Learning and Curriculum Studies, Mzuzu University, Malawi.

\begin{abstract}
The study argues that student-teachers on teaching practicum (TP) find it hard to implement learner-centred activities through the challenges of some written remarks (comments) by supervisors on the observation form (tool). In addition the assessment (score) as shown on the observation form correlates with learner-centred activities as well. This study wanted to establish whether the observation form matches well with activities of PDSI-ASEI using this as an indicator of learner-centred strategy. A random sample of 50 observation forms were used to find out the supervisors' remarks and an observation of 35 lessons during the third and second visits to schools using a check list of items containing some ratings as very often, often, rarely and never. In addition, a semi-structure interview followed using the same student-teacher. The study has shown that supervisors remarks contribute to student-teachers challenges in implementing learner-centred citing that the remarks are brief and their meanings could not be established. In some cases, the supervisors' remarks are not expressed very well for the student-teacher to comprehend elements of learner-centred. However, some students do value these remarks and take them to incorporate in their practices while others disregard such remarks based on the way how supervisors have framed them. Further the study reveals that the observation form and activities of PDSI-ASEI model agrees on several items except very few of them requiring a review of the tool.
\end{abstract}

\section{Keywords}

Learner-Centred, PDSI-ASEI Strategy, Teaching Practicum, Observation Form, Student-Teacher and Supervisor

\section{Introduction}

Kiggundu, E., \& Nayimula, S.(2009), argued that teaching practice is an integral component of teacher training. It grants student-teachers experience in the actual teaching and learning environment. Student-teachers gain practical experience in a classroom teaching to learners and outside a classroom through other duties. Mzuzu University education programme allows students who are enrolled for bachelor of education programme to do Teaching Practicum (TP) as a requirement for completion of the programme. In preparing students for teaching practicum students have to acquire knowledge of the content in the subjects they will teach together with subject's methodologies and the education foundation courses. Considering that teaching 
involves the imparting of information to the learner in a manner of constructing knowledge and skills for better understanding of concepts, initially it requires proper and effective preparation and planning as a way of good method delivery. In a study by Qazi, W., Rewat, J. K., \& Thomas, M., (2012),they found out that most teacher education institutes prepare their student teachers for teaching in the real classroom contexts through "the practicum" that is a teacher education course unit consisting of both theoretical and practical aspects. There are several teaching methods students learn in preparation for this teaching professional, however not all methods engage learners appropriately. It should also be noted that teaching methods are developed from various theories of teaching and learning with the sole purpose of making flow of ideas between the teacher and learner in a classroom. Following the PDSI-ASEI approach (Peter M.B, 2010) students can gain more and better skills of teaching in order to promote the use of learner-centred approaches. Through proper Planning, Doing (teaching) and seeing how the lesson unfolds then we can improve on and on for the better. The principles of ASEI/PDSI approach serve as a foundation upon which teachers can build a substantive and sustainable change in classroom practices with the ultimate aim of enhancing the quality of teaching/learning (Mwangi J .K., \& James , O.A.,2010)

In such scenarios activities for student teaching need to include hands-on and provide an opportunity for more learner engagement. These items in PDSI-ASEI approach are the indicators of learner-centred teaching and this study has focused much on them to guide the process. As such, it is believed that when teachers have knowledge of this approach learners can have an autonomy of their learning for better knowledge construction. It is understandable that great teachers maximize the opportunities for students to learn, but even the greatest teachers cannot guarantee learning. Teaching Practicum (TP) is an activity conducted by student-teachers in schools for a specific period of time to practice newly concepts learned from this training institution. As such TP helps student-teachers master and gain suitable skills of classroom teaching with learners before assuming the role of a full teacher. In the activity, the student-teacher teach and deliver lessons to actual learners in a class after planning and preparing lessons. During this period supervisors (who are lecturers) from Mzuzu University visit student-teachers to supervise using an observation tool (form). An observation tool is model designed with a purpose of guiding teaching and learning. It has items appropriate for training a teacher at Mzuzu University with an aim of expecting a secondary school learner to be engaged accordingly through some class activities. In addition, the tool is designed to assess student-teachers on how they use items which are listed from planning, class management, methods and resources, learner engagement, questioning techniques, introduction and closing of lessons. Though this is the case, some students are unable to apply learner-centred approaches even though the observation tool addresses. When such student-teachers are visited for the second and third times they do not seem to put into practice some of the items in the observation form adequately including those that characterise learner-centeredness. It is believed that this lack of learner-centred skills is developed due to a result of many factors within players of the teaching practicum. However, in this paper we looked at some selected remarks (comments) on the observation form by the supervisors whether they address and emphasise elements which are learner-centred for student-teachers to put into effect. In other ways the study wanted to understand the interrelationships between what supervisors write in an observation form and student-teachers' practices of learner-centred as they conduct teaching practice in schools. This prompted the question: How are learner-centred approaches being implemented through the use of an observation tool during the teaching practicum; the case of Mzuzu University Teaching Practicum (TP).

\subsection{Purpose of Study}

To address whether the remarks by supervisors in the observation tool promotes learner-centred strategies for student-teachers during teaching practicum (TP).To establish whether there will be need to review the observation too to suit some elements appropriately for training teachers during teaching practicum.

\subsection{Specific Objectives}


- Analyse items which are learner-centred in the observation form

- Identify remarks by supervisors in the observation form in relation to issues of learner-centred approaches

- Find out the impact of supervisors' remarks on the observation tool to the student-teacher.

\subsection{Significance of the Study}

The results of this study will help supervisors to gain knowledge of learner-centred before they observe lessons during teaching practicum. In addition student-teachers will be able to see the remarks by supervisors as more important in the implementation of learner-centred classrooms. By comparing the observation tool with characteristics of PDSI-ASEI as advocated by SMASSE it will lead to make the tool more effective for producing quality teachers. Furthermore the study will be an eye opener for the administrators to review the observation tool for teaching practicum to capture other items that are not utilised for the promotion of learner-centred approaches.

\subsection{Statement of the Problem}

Learner-centred approach has been regarded as one of the best approaches for engaging learners in a classroom. As a teacher training institution, student-teachers develop the need for having learner-centred approaches skills as an integral for effective classroom activity engagement. During teaching practicum activity, classroom observation tool plays an important role in guiding the student-teacher appropriately in order to achieve quality teaching. However, experience has shown that some student-teachers do not put these elements of learner-centred into effective practice when presenting their lessons and furthermore, it shows that majority of student-teachers don't effectively apply leaner -centred strategies in schools after graduating. Yet during teaching practicum supervisors carry with them to class an observation form and write remarks based on what has been observed in class. Hence the study would like to find out whether the classroom observation tool effectively support (promote) learner-centred activities to preservice teachers, and how do student- teachers value items on the observation form and its remarks (comments ) by supervisors.

\section{Theoretical Framework}

\subsection{Constructivism Theory and Teaching}

This study is based on the theory of constructivism on how people learn. It says that people construct their own understanding and knowledge of the world, through experiencing things and reflecting on those experiences. Cathcart W.G., (2004) advocates that knowledge is actively constructed by the individual. A constructivist believes that the learner constructs his/her own knowledge. In the classroom, there must be a high level of learner interaction, an emphasis of learner autonomy or responsibility, and group work would characterise a constructive environment. In this setting the teacher is responsible for establishing a learning environment that will spark children's interest. Qiong Jia ( 2010) further pointed out that constructivism learning theory is the further development as behaviourism arrives at cognitivism. According to its teaching theory: knowledge is uncertain; the learning process of knowledge is also the construction process of knowledge; students are the main body of learning activity and they construct knowledge on their own initiatives; teachers are the helpers and the drivers for students constructing knowledge. In addition this theory emphasises that students are the subject in teaching. The study by Ochong'a O.B., (2013) argued that the constructivist framework portrays an active human agent who knows the world by transforming it and actively adapting to its constraints. When something new is encountered, it has to be reconciled with previous ideas and experience. In a constructivist classroom, it means encouraging students to use active techniques such as experiments to create more knowledge. Constructivist teachers encourage students to constantly assess how an activity is helping them gain understanding. When they continuously reflect on their experiences, students find their ideas gaining in complexity and power, and they develop increasingly strong abilities to integrate new information. One of the teachers' main roles becomes to encourage this 
learning and reflection process. Teachers should offer more humanism cares for students and create a favourable teaching environment for students. It emphasizes on the initiatives and the interaction in teaching. Students should focus on exploration learning and cooperative learning based on previous knowledge and experiences by means of interactive actions. In cooperative learning learners must talk with one another-engage in discussion of all problems. Posamentier A.S., (2006) observes that there must be small groups and meaningful tasks for learners to share and think as they construct meaningful learning. Aminah, J. R., \& Asl, D. H. (2015) further explains that constructivism is a synthesis of multiple theories diffused into one form. It is the assimilation of both behaviorialist and cognitive ideals. Mvududu and Thiel-Burgess (2012) state that constructivism is widely touted as an approach to probe for children's level of understanding and to show that understanding can increase and change to higher level thinking. Thus, constructivism refers to how of learning and thinking. Constructivism describes the way that the students can make sense of the material and also how the materials can be taught effectively. With Constructivism as an educational theory in mind, the teachers should consider what students know and allow their students to put their knowledge into practice. For Piaget, knowledge construction takes place when new knowledge is actively assimilated and accommodated into existing knowledge. Furthermore, Piaget's constructivist stances are seen in his belief that our understandings of reality are constantly being revised and re-constructed through time and with respect to exposure to new experiences. "What remains is construction as such, and one sees no ground why it should be unreasonable to think it is ultimate nature of reality to be in continual construction instead of consisting of an accumulation of ready-made structures" (M. Gail Jones and Laura Brader-Araje., 2002).

\subsection{PDSI-ASEI Approach in Teaching and Learning}

The study also considers ASEI/PDSI where ASEI means activity, student, experiment and improvisation while PDSI means plan, do, see and improve. Kiige, J. M., \& Atina, O. J. (2016) pointed out that the ASEI/PDSI approach aims at equipping teachers with necessary skills for classroom practices that are activity oriented in order to create an opportunity for learners to take responsibility for their own learning. It encourages teachers to practice student-centered teaching and learning. Emphasis is laid on employing inquiry-based and problem-solving learning as opposed to lecture style and recipe-type approach to experiments. In addition improvisation is encouraged not only to augment conventional equipments, apparatus and materials but also to arouse interest and curiosity among the learners. This theory is based on from ineffective learner to effective learner ASEI /PDSI Pedagogic Paradigm Shift. Ochongó, B.O., (2013) supports the idea of ASEI-PDSI as a strategy promoting learner centred approaches. In order for the ASEI-PDSI approach to be effectively implemented, teachers require an adequate understanding of the approach and its components. The approach entails activity focused teaching and learning, which calls for use of varied, appropriate and interesting teaching and learning activities by teachers, as well as having students conduct practical work; student-centred teaching and learning, which calls for greater involvement of the learner in the learning process-this is done through effectively encouraging students to give their prior experiences and explaining their ideas related to the content; effectively encouraging students to give their own hypotheses/predictions and helped to discuss how they differed from those held by others and to verify them through experiments; effectively encouraging students to give their own observations and results in experiments and to discuss how they differed from those of others; and encouraging students to evaluate the lesson; experiments: students should be given opportunities to perform experiments which enhance understanding of concepts in mathematics and science- this is evidenced by the ability of students to solve related problems; ability of students to make deductions from practical work; and the ability of students to verify hypotheses and predictions; and improvisation: this calls for innovativeness and creativity on the part of the teacher and it involves improvising using materials available in the immediate environment of the students to give experiments and also arouse interest and curiosity in the learners-this is evidenced by the conduct of modified/simplified experiments; utilization of materials available in the students immediate environment; teacher 
producing and or utilizing improvised materials; ability of the students to effectively use improvised materials; and enhanced students ${ }^{\text {ee }}$ participation. The following are the principles of ASEI: Knowledge-based teaching to be replaced by activity-based teaching; Student-centred learning to prevail over teacher centred teaching; Experiment and research-based approaches to replace the traditional lecture approach; and Improvisation and small-scale experiments to replace large-scale experiments (www.SMASSE.org/E/indexe.html). According to Ayiego, E. M.,Mang'are P. A., Ngome, C. K.,\& Mandilah, (2015) the Student-Centered Experiment and Improvisation (ASEI) Approach considered quality of classroom activities as critical to achieving effective teaching and learning and hence good performance in Mathematics. These are meaningful hands on (manipulation), minds-on (intellectual thinking, reasoning) mouths-on (discussions), heart-on (those that stir up the learners' interest or feelings about the subject) activities. ASEI-PDSI approach stressed on the need for the learners to carry out a well planned learning activity that involves seeing and improving the activity hence promoting effective learning take to place. The ASEI-PDSI initiative focuses on teachers to reflect on their teaching strategies and acquire skills for effective teaching and efficient learning to occur.

\section{Literature Review}

\subsection{Learner-Centred Approaches}

This study is based on the theory of leaner-centred approach which is more enquiry based, learning by doing sort of thing. In learner-centred approach, the student often has to "discover" by himself the notions to be acquired. The teacher no longer provides knowledge but organises the conditions that would help the students acquire the knowledge; the teacher is often seen as a facilitator. Peter, M.B.,(2010) define student-centered learning as: ways of thinking about teaching and learning that emphasize student responsibility and activity in learning rather than content or what the teachers are doing. It is believed that all good learning and teaching is learner-centred, in that sense that it depends on the learner's interest, engagement, and competence. But, to be learner-centred does not mean everything is driven by the learner. In fact, it is very much a give-n-take relationship that happens between the learner and the teacher. There are ample times when a learner needs a teacher to drive the learning, to direct, to guide, even to discipline. A learner-centred teacher is one who always tries to figure out when she should do a lot for the learner, and when she needs to pull back - back to the Vygotsky's scaffolding notion. But being able to successfully do the work in a learner-centred classroom will require most students to advance their learning skills. The learner does most of the class activities both hands-on and minds-on activities, which means that the centre of all activities is the learner and the teachers role is to guide. Flores Angel, (2010) argues that learning arises in a social context of collaboration and harmony, and the teacher is a guide that leads the process, designs the teaching activities and monitors the whole process. Furthermore, learner-centered pedagogy emerged from constructivist learning theory and represents countermovement to traditional teacher-centered pedagogical practices (Baeten, Dochy, \& Struyven, 2012; McAuliff \& Eriksen, 2002). Educators who use learner-centered pedagogy view knowledge through lenses of social and relational processes and therefore prioritize students' individual processes of constructing personal knowledge and understanding rather than rote mastery of course content (Baeten et al., 2012). The primary task of an instructor using a learner-centered approach is to create an environment that is conducive to learning. Although a strong grasp of course content and use of lecture may be helpful in this endeavour, they represent only two of several important components of such a learning environment. Brown (2003) stated that the focus on the process of learning and the context in which learning occurs is considered to be as integral as, or more integral than, the specific content knowledge presented to students. McCombs (as cited in Cornelius-White, 2007) described some characteristics of learning environments that are based on learner-centered assumptions:

[Learning is] non-linear, recursive, continuous, complex, relational, and natural in humans... Learning is enhanced in 
contexts where learners have supportive relationships, have a sense of ownership and control over learning processes, and can learn with and from each other in safe and trusting learning environments.

Two important components that learner-centered teachers consider when establishing a positive learning environment are providing supportive relationships in the classroom and creating a space that feels safe and trusting to student learners (Weimer, 2002). Instructors using a learner-centered approach foster supportive relationships and cultivate a safe learning environment by diffusing power differentials between the teacher and students. Instructors diffuse power differentials through intentionally creating opportunities for students to become active in the classroom, honouring and utilizing student learners' individual experiences and perspectives, and treating students as partners in the learning process (Crick \& McCombs, 2006). Thus, instead of the instructor being the primary arbiter of content, intellectual queries and structure in a classroom, a learner-centered instructor favours democratic and collaborative approaches to teaching that empower students to be active participants in their learning (Wright, 2011).There are characteristics that you have to look for in order to evaluate if a methodology is learner-centred: These characteristics are those from PDSI-ASEI strategies and are intrinsic motivation instead of extrinsic motivation and based on the learner's needs and interests. It is observed that learner-centered should encompasses methods of teaching that shift the focus of instruction from the teacher to the student. In original usage, student-centered learning aims to develop learner autonomy and independence by putting responsibility for the learning path in the hands of students. This approach, focuses on skills and practices that enable lifelong learning and independent problem-solving.

\subsection{Teaching Practicum}

This is an activityconducted with students on education programme to gain skills and knowledge of what they had been learning during their training in college/university to a school with learners for a certain period of time. According to Racine, D., (2016) Practicum refers to experiences that teacher trainees have in the classroom before they take on the full range of responsibilities required for student teaching. Practicum teachers partner with a professional teacher who directs their activities and gives them feedback on any work they do. In most practicum experiences, education majors will do a combination of observation and classroom assistance. At times, they will simply watch the class, record their observations, and ask questions to their cooperating teacher outside of class time. At other times, practicum teachers will actively help their cooperating teacher, working directly with the students. They may even teach a few lessons themselves, with a professional teacher-and perhaps also a faculty member from their university-present in the classroom to supervise them and give them feedback. Marais and Meier (2004:221) further alluded that the term teaching practice represents the range of experiences to which student teachers are exposed when they work in classrooms and schools. In addition teaching practice is a challenging but important part of teacher training, especially in developing countries like Malawi, where the effectiveness of the teaching practice can be diminished or eroded by a range of challenges, such as geographical distance, low and uneven levels of teacher expertise, a wide-ranging lack of resources as well as a lack of discipline among a wide cross-section of learners and educators. In study by Qazi,W.,Rewat,J.K.,\& Thomas, M., (2012), found out that most teacher education institutes prepare their student teachers for teaching in the real classroom contexts through "the practicum" that is a teacher education course unit consisting of both theoretical and practical aspects. Barry and King (2002) note that, "Teaching practice [practicum] provides the opportunity to apply the principles of teaching and learning that have been studied during course work" (p. 35). Research studies suggest that student teachers view their practicum experiences as extremely important and essential for their induction into professional life (Zeichner \& Gore, as cited in Keogh, Dole, \& Hudson, n.d.). They believe that the practical experiences of supervisors who observe their lessons, receiving feedback and practicing various teaching strategies during the school experience are the most important factors in student teachers' professional growth (Tisher, as cited in Atputhasamy, 2005). Feedback on classroom 
performance often takes the form of a supervisor's comments immediately after the lesson is over. This must be followed by another attempt at the lesson and then evaluation for improvement. Among the important skills Mzuzu University advocates as a requirement by a student-teacher are: Planning skills; Lesson presentation skills; Questioning skills: Class organization skills (classroom management); Use of methods \& resources; inclusion of learner engagement and activities; and, Evaluation skills. Planning skills include preparation of lesson plan and devising instructional procedures to achieve the stated instructional objectives. To effectively present a lesson, a student-teacher needs to be skilful in set induction, closure, varying the stimulus, clarity of explanation and using familiar examples for clarifying explanation, and concept formation. However, teaching practice provides student teachers with the opportunity to integrate the theory of education with that which they are experiencing at first hand. Furthermore, Perry (2004:4) noted that, although students gain much specialised knowledge by attending lectures and doing assignments, teaching practice adds meaning to this knowledge when a student teacher comes into contact with the real classroom situation. It is during teaching practice that knowledge is affirmed.

\subsection{Role of Supervisors}

When student-teachers are allocated to various schools for practicing teaching, supervisors who are also lecturers form the university visit them at least three times. The supervisors are oriented on their roles with the guide of an observation form which acts as a guide during the process of teaching practice. Every supervisor must first have skills of teaching and knowledge of what the observation form requires in guiding the student-teacher. The role of the Teaching Practice Supervisor is focused on monitoring and evaluating the practices and behaviours of the student-teachers including dealing with errant student teachers. The school shares responsibility with the supervisor for supporting the student teacher in lesson planning, observation and feedback as well as demonstrating teaching skills and counselling them.

The role of the supervisor is among others involves giving guidance to lesson preparation and presentation; advising on classroom management and organisation; supervising and evaluating a student teacher's performance in practice teaching situations and discussing his/her progress with him/her; consulting with the institution and the student teacher regarding the student teacher's development. An important part of effective professional practice is collecting evidence that provides the basis for ongoing feedback, reflection and further development. The complex work of teaching generates a rich and valid range of evidence that can inform meaningful evaluations of practice for both formative and summative purposes. Potential sources of evidence include evidence of the impact of teaching on student outcomes and evidence of professional teaching.

\section{Methodology}

This study was based on learner-centred pedagogy which is a component of PDSI-ASEI strategy for promoting constructivism in learning. The study focused on learner-centred through the use of a teaching practicum observation tool used by Mzuzu University when training student-teachers in schools. In order for the TP to be effective enough supervisors write comments (remarks) in an observation form as feedback to student-teachers in order to improve their teaching on those items characterising effective teaching and learning. Some comments which are written on the observation tool became difficult for student-teachers to comprehend and put them into practice. The reasons could be many however this study will help us find out. In general sense this shows that the tool is not clearly addressing what student-teachers need to know and use when they are left alone to teach in their classrooms.

\subsection{Research Design}

This was a survey targeting student-teachers and supervisors comments in the teaching practicum (TP) observation tool. In order for this study to be conducted PDSI-ASEI strategies has been considered as a model. In other ways the indicators of 
learner-centred techniques for TP observation form are drawn from PDSI-ASEI strategies. This survey also had a follow up to schools to see how students are using what they were already advised by their supervisors based on the remarks included in the observation form. The research is a qualitative one since will give a descriptive presentation on what may have transpired.

\subsection{Data Collection}

Involves comparing and reading the comments by supervisors on a classroom observation form. The reading of the remarks were mainly focusing on the comparisons to the actual form and targeting those items that are learner-centred as regard to PDSI-ASEI guide lines. Using follow ups to school with a check list of items to find out whether any improvements have been made by student-teachers. In addition, by collecting data on the results of the 2nd and 3rd visits on their observation forms (which was done to all students) also helped to establish whether there were some changes on student-teachers' use of learner-centred approaches or not. Responses were analyzed and grouped into common sets of themes; for example, the importance of associate teachers as role models, personal pedagogy, reflection, feedback, communication styles and relationships, personal professional qualities, self efficacy and successful associate teachers.

\subsection{Sampling Technique}

A sample of 50 observation tools filled by supervisors in the first visit to schools was used and 35 student-teachers were sampled for this study. These student-teachers were selected randomly just for schools closer to the researcher for easy and proper follow up to schools. Observation was done three times per student-teacher. So the second and third visit helped to find out whether students are improving or not in their teaching period of practice. These 35 students were interviewed to learn from them how they feel about the observation tool and remarks written in their forms. Student teachers were interviewed by means of a semi-structured face-to-face interview about their feelings on the supervisors remarks in the observation form. The questions asked were those related to the observation form and the supervision remarks about their feelings and understanding of learner-centred approaches. It was also important to compare student-teachers assessment scores in the observation form whether there is correlation with learner-centred approaches.

\subsection{Data Analysis}

This was a qualitative study and however some data was presented in tables using Microsoft word Excell and followed by descriptive ideas.

\subsection{Dissemination of Findings}

The findings of this study are for conference presentation to gain more inputs to ensure that the paper becomes more original.

\section{Findings and Discussion of Results}

The ASEI-PDSI guidelines were used as indicators for learner-centred strategies compared with an observation form.

Observing the items for the two guide lines as in Table 1 it is clearly understandable that there is a provision of guiding principles on what a student-teacher can do to address learner-centred activities during the teaching practicum. In turn, they also inform what the supervisor has to dwell on when supervising student-teachers. In the classroom, there are various ways of presenting a lesson however the use of the observation form based on indicators of learner-centred drawn PDSI-ASEI will make a good lesson for learner engagement. In addition they will also help the learner in a classroom to construct knowledge through the activities and participation which is provided for by their teacher. This will also entail that learners can develop critical thinking minds. Generally, this observation form has those elements which are learner-centred, it only requires to make it more 
explicit or very clear on what the supervisor and the student-teacher have to do to make both of them comfortable in handling the observation form. PDSI-ASEI approaches can improve the teaching and learning process through providing an effective supervision means. The supervision can support the student-teacher in those areas deemed lacking attention on the teacher.

Table 1. Showing PDSI-ASEI as an indicator of learner-centred for classroom observation tool.

\begin{tabular}{|c|c|c|c|}
\hline $\begin{array}{l}\text { Selecting items on Observation } \\
\text { Form }\end{array}$ & $\begin{array}{l}\text { Items required by } \\
\text { PDSI/ASEI }\end{array}$ & Similarities & $\begin{array}{l}\text { Shortfalls in the observation } \\
\text { tool }\end{array}$ \\
\hline
\end{tabular}

Table 2. Showing comments by supervisors from an observation form.

\begin{tabular}{|c|c|}
\hline $\begin{array}{l}\text { Items on } \begin{array}{l}\text { Observation Form } \\
\text { containing } \\
\text { lets) }\end{array} \\
\end{array}$ & Characteristics of learner-centred \\
\hline $\begin{array}{ll}\text { Planning and preparation } \\
\text { - } \\
\text { - } & \text { Appropriate } \\
\text { - } & \text { Proper activities chosen } \\
\text { - } & \text { Sequenced content } \\
\text { - } & \text { Suitable } \\
\text { - } & \text { Objectives matches with content } \\
\text { - } & \text { relevant } \\
\text { - } & \text { Learner-centred } \\
\end{array}$ & $\begin{array}{ll}\text { - } & \text { No } \\
\text { - } & \text { Yes } \\
\text { - } & \text { Yes } \\
\text { - } & \text { No } \\
\text { - } & \text { No } \\
\text { - } & \text { Yes } \\
\text { - } & \text { No } \\
\text { - } & \text { Yes } \\
\end{array}$ \\
\hline $\begin{aligned} \text { Knowledge of subject matter } \\
\text { - } \quad \text { Well done } \\
\text { - } \quad \text { Knowledgeable } \\
\text { - } \text { Relevant } \\
\text { - } \text { Provoking thought } \\
\text { - } \quad \text { Good command of subject matter } \\
\end{aligned}$ & $\begin{array}{ll}- & \text { No } \\
\text { - } & \text { No } \\
\text { - } & \text { No } \\
\text { - } & \text { No } \\
\text { - } & \text { Yes } \\
\end{array}$ \\
\hline $\begin{array}{l}\text { Teaching and learning methods } \\
\text { - Interesting and appropriate } \\
\text { - } \quad \text { class discussion } \\
\text { - } \text { Learners working in groups } \\
\text { - Appropriate } \\
\text { - Learner involvement } \\
\text { - Learners participated fully } \\
\text { - Appropriate teaching strategies } \\
\text { - Meaningful } \\
\text { - Relevant }\end{array}$ & $\begin{array}{ll}\text { - } & \text { No } \\
\text { - } & \text { Yes } \\
\text { - } & \text { Yes } \\
\text { - } & \text { No } \\
\text { - } & \text { Yes } \\
\text { - } & \text { Yes } \\
\text { - } & \text { No } \\
\text { - } & \text { No } \\
\text { - } & \text { No } \\
\end{array}$ \\
\hline $\begin{array}{cc}\text { Use of } & \text { teaching and learning } \\
\text { - } & \text { Varied } \\
\text { - } & \text { Chart not used properly } \\
\text { - } & \text { Effective use of aids } \\
\text { - } & \text { Teaching methods not used well }\end{array}$ & $\begin{array}{ll} & \\
\text { - } & \text { No } \\
\text { - } & \text { No } \\
\text { - } & \text { Yes } \\
\text { - } & \text { No } \\
\end{array}$ \\
\hline
\end{tabular}




\begin{tabular}{|l|l|}
\hline$\bullet \quad$ Resourcefulness & $\bullet$ Yes \\
$\bullet \quad$ Meaningful and suitable & $\bullet$ No \\
\hline $\begin{array}{l}\text { Learner activities } \\
\bullet \quad \text { Meaningful activities }\end{array}$ & \\
$\bullet \quad$ Learners not engaged & $\bullet$ No \\
$\bullet \quad$ Good but should do more & $\bullet$ Nes \\
\hline Use of evaluation tools & \\
$\bullet \quad$ Mixed ability & $\bullet$ yes \\
\hline Classroom management & \\
$\bullet \quad$ Equal opportunity, & $\bullet$ Yes \\
$\bullet \quad$ Teacher provides support & $\bullet$ Yes \\
$\bullet \quad$ Class well managed & yes \\
\hline
\end{tabular}

From the table there are mixed responses by supervisors comments based on how they observed a lesson from a student-teacher. Some comments are very much in support of learner-centred while others are difficult to conclude whether they are supporting learner-centred. The observation form has some guidelines for supervisors to write classroom remarks when observing a lesson presented by the student-teacher. Supervisors have always held sharp differences of opinion about their knowledge of items in the observation form and how to connect with what student-teachers do in the classroom. These differences mark the history of supervision, surfacing both in internal struggles over mission and a more external struggle for identity as a distinct field of practice. Borko and Mayfield (1995) found that some supervisors focused on superficial aspects of teaching, such as paperwork, lesson plans, and behavioral objectives, and avoided in-depth discussions about content and pedagogy, and thus, offered student teachers no specific directives on how to change their practice. Supervisors should actively participate in student teaching and challenge student teachers' existing beliefs and practices and model pedagogical thinking and actions. In short, active participation in student teaching will require more than peripheral commitments by the supervisor but could result in a practicum that functions as teacher education, not just teacher evaluation. The complexities of teaching require pre-service teachers to firmly assess their own attributes, attitudes, and competencies to ensure academic success in the teaching and learning process. To this end, the university supervisor serves in several capacities (consultant, facilitator, mentor) while providing support in both a clinical and practical approach.

\subsection{Findings from $2^{\text {nd }}$ and $3^{\text {rd }}$ follow Ups on Observation Forms and Classroom Observations}

Classroom observation for the 35 student-teachers.

a) Using a check list with PDSI-ASEI guidelines.

Student-teachers were observed in their classrooms to find out if there is an improvement in using learner-centred approaches often or never.

Table 3. Observation form.

\begin{tabular}{|c|c|c|c|c|}
\hline ITEMS observed & Very often & often & rarely & Never \\
\hline Planning ( objectives linking to content) & 14 & 7 & 14 & \\
\hline $\begin{array}{l}\text { Knowledge of content by student } \\
\text { teacher }\end{array}$ & 23 & 8 & 4 & \\
\hline Time for activities & 6 & 12 & 7 & 10 \\
\hline Methods used ( participatory, varied) & 4 & 7 & 11 & 8 \\
\hline $\begin{array}{l}\text { Student activities( task oriented, } \\
\text { knowledge construction) }\end{array}$ & - & 2 & 15 & 13 \\
\hline $\begin{array}{l}\text { Assessment ( reporting and connecting } \\
\text { to objectives) }\end{array}$ & & 3 & 10 & \\
\hline
\end{tabular}


Observing from both Table 3 and bar chart (Figure 1) show that student-teachers have knowledge of content and are able to apply in their planning of lessons and what will be done in the classroom with their learners. Most of the student-teachers never apply learner activities as required or planned in their lesson and time for activities in some cases for learner discussion never considered important in other lessons. The methods commonly used were question and answer and students were put in groups to discuss but the kind of tasks not thought provoking for learners to construct meaningful ideas for the lesson. Atwood, S., et al. (2011) further alluded that learning and development occur through opportunities to engage with the ideas and perspectives of others, often through conversation and social interaction. As such it is proposed that the construction of knowledge is facilitated in cooperative as opposed to constraining relationships. In short, active participation in student teaching will require more than peripheral commitments by the supervisor but could result in a practicum that functions as teacher education, not just teacher evaluation.



Figure 1. Observation form.

Table 4. Observation form and supervisors comments.

\section{The Observation form}

A good guiding tool; Learner-centred is promoted but not effective; relevant items for TP; Promotes activities in learning,

Encourages variety of methods;

Too many information in one lesson; shows link to theory and practice; Informs about classroom practices, is about knowledge and skills of teaching

\section{Supervisors comments}

Brief, unable to listen to our ideas; time not adequate for discussion; It confuses student-teachers to grasp important items; Form is briefly written so unable to grasp its meaning; Not well emphasised or not well explained by supervisors; some ideas about learner-centred shown; some supervisors need more knowledge on the form about teaching; knowledge and skills provided; informs about teaching and classroom practices.

The Table 4 shows a presentation of results from structured interviews conducted to student-teachers and the use of the observation tool as guided by supervisors remarks (comments).

It is observed that students view both the supervisors comments and observation tool as critical in learner-centred approaches guiding principles. They do their practices with regard to what has been advised in both situations. On the supervisors comments some students do not understand some of the comments put forward by their supervisors on the observation form. As such most student-teachers find it hard to interpret the meanings of the comments and resulting into inadequate practice on such issues about learner-centred. Though there are some challenges still some ideas of learner-centred are practiced but not as effective as it is supposed to be done. Some of the challenges as reported by student-teachers included: 
[student-teachers] ... On our part we could not put some items into practice due to other challenges; Different supervisors bring confusing ideas on us, Difficult to follow some important items written by supervisors, they are brief, supervision varied with different teachers, large classes; not adequate time for talking on feedback.

Therefore there is a need for positive, personal and professional relationships between the supervisor and student teacher, involving open and frank communication. It is a necessary prerequisite for a successful practicum that students have a supervisor who is communicative, reflective and supportive and has clear beliefs and philosophies in regard to teaching and supervision. Learning to teach is an activity that depends upon social interactions, and for this reason associate teachers should supervise student teachers' learning by being supportive of their acquisition of professional and practical skills. There is a clear link between a positive practicum experience and excellence in supervision (Beck \& Kosnik, 2002) and it is important to identify those factors which make the greatest difference for student teachers. During the feedback conference the university supervisors should concentrate on constructive analyses and reinforcement of successful patterns based upon observational evidence (Coates, D.Y., 2015) (as cited in Hopkins \&Moore, 1992 ). More specifically, this is the opportunity to reflect objectively on the teaching experience and to apply concepts for self-assessments building upon the identified strengths and recognizing the areas for improvement.

\subsection{What Student-Teachers' Grades Mean on Learner-Centred}

Assessment as indicated in the student-teachers observation forms also shows some correlation with learner-centred approaches (Table 5).

Observing from what student-teachers scored we can clearly conclude that each corresponding range of marks is related with activities and learner participation in a classroom. The observation form shows that it has more items of classroom activities than any other items like time management. In a classroom which is characterised with classroom discourse and high level of learner engagement, with resources and manipulatives, the supervisor will consider it as more important for adequately placing the student-teacher on appropriate scores. Observing from the table it is noted that the assessment with satisfactory is an indication of low learner-centred activities. Which means that the student-teacher did not do enough to engage his/her learners in the classroom. Only very few student-teachers score better marks on their observation forms as compared to those few who scored very good and excellent. This is where we see that student-teachers did not improve despite being visited three times. This is where a competent supervisor would be required to write comments very clearly for an effective feedback to the student-teacher. Student- teachers are learners too and they need to gain skills and knowledge to be able to help them teach effectively. The supervisors need to work with student -teachers helping them and later use this knowledge to improve their teaching.

Table 5. The student-teachers observation forms.

\begin{tabular}{llll}
\hline Graded observation Forms & Range of marks & Frequency & Learner-centred indicators \\
\hline Satisfactory & $50-59$ & 9 & Low \\
Good & $60-69$ & 16 & Partially done \\
Very good & $70-79$ & 8 & Better done \\
Excellent & $80-100$ & 2 & Adequately done \\
\hline
\end{tabular}




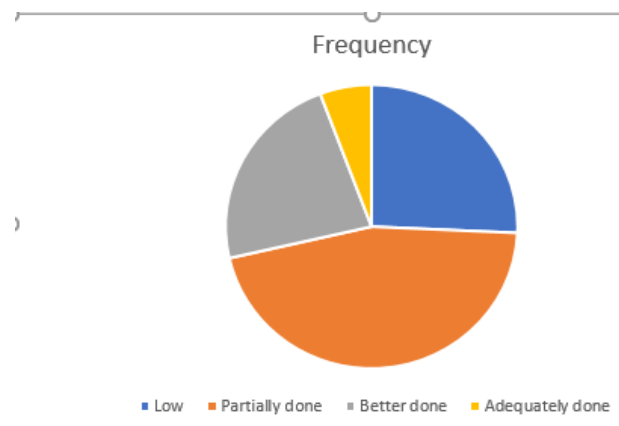

Figure 2. Observing from.

\section{Conclusion, Recommendations and Areas for Further Studies}

This study involved an observation form, supervisors comments and learner-centred strategies through PDSI-ASEI approaches, as such more areas have been considered. Supervisors play an important role in ensuring that the observation form communicates important ideas to the student teacher. What students are supposed to do must help learners to learn and construct ideas through activities. It has been found that the remarks from supervisors are very important in supporting student-teachers develop appropriate skills and knowledge of learner-centred. Using the PDSI-ASEI model as indicators of learner-centred approaches shows that the observation form used by Mzuzu University to train teachers is a good one only requiring a few areas to be amended to suit what PDSI-ASEI advocates for quality training of teachers. Several studies (Kiige, J. M., \& Atina, O. J., 2016., and Ochongó, B.O., 2013) support that when PDSI-ASEI approaches are used in a classroom they promote life-long learning. Furthermore, during teaching practicum student-teachers can have an opportunity to gain knowledge and skills of using PDSI-ASEI approaches for the benefit of learners not only in sciences and mathematics subjects but also in any other course of study. The study has also revealed that learner-centred by student teachers has not been effective due to a number of factors one of them is their failure to understand the comments (remarks) from supervisors to transform them into practice of learner-centred approaches. The short and unclear statements by supervisors have contributed to student-teachers lacking good and effective communication about what the observation form addresses. This requires more knowledge on part of supervisors to see the importance of what they write and how students-teachers put them into effective practice in a classroom setting. Student-teachers can practice effectively in a classroom setting learner-centred approaches provided the time for feedback is used properly with their supervisors. The study has revealed also that student-teachers cannot teach effectively in a classroom due to lack of learner-centred skills.

\subsection{Recommendations}

The study has find out that student-teachers are challenged when using learner-centred approaches due to the way how the observation form guides them and the remarks (comments) written by supervisors. Student-teachers have argued through interviews that the observation form emphasises on general items about teaching not necessarily focussing specifically on learnercentred approaches. So student-teachers just go into the classroom to present lessons as guided by the observation form ,however, when observing their lesson presentations you would be able to get some elements of learner-centred activities being applied but not effective.

The study recommends that student-teachers be told that the items which are in the observation form promotes learner-centred and only need to be knowledgeable on what learner-centred practices involves before going to do TP in schools. 
Student-teachers say that supervisors need to learn better ways of communicating to students-teachers after the lesson has been observed to pave way for improving learner-centred lessons.

Having noted that the remarks by supervisors are crucial for teaching practicum and supporting student-teachers in promoting learner-centred, then supervisors need to present their remarks clearly and consciously. This informs the need to advise all supervisors on better ways of writing accurate and proper comments on observation forms before visiting student-teachers.

It has also been noted that the observation form and the PDSI-ASEI guidelines play a similar role based on some items each of them poses and as such leaders of TP must consider making it more appropriate as a guiding tool for promoting learner-centred approaches in the classroom. In addition emphasis should also be to those who train student-teachers on the need to ensure adequate preparation is conducted on learner-centred to all student-teachers before going to practise in schools.

\subsection{Areas for Further Studies}

Do the period of supervision have an effect on student-teachers during teaching practicum. Grouping student-teachers of similar subjects in one school for TP: a make or break for effective practice.

\section{References}

Atputhasamy, L. (2005). Cooperating Teachers as School Based Teacher Educators: Student Teachers' Expectations. Australian Journal of Teacher Education. 30 (2), Retrieved February 4, 2008 from http://ajte.education.ecu.au/issues/PDF/Thirtytwo/atputhasamy.pdf Atwood, S., Turnbull, W., \& Carpendale, J. I. M. (2010). The Construction of Knowledge in Classroom Talk. Journal of the Learning Sciences, 19(3), 358-402.

Ayiego, E . M.,Mang'are P. A., Ngome, C. K.,\& Mandilah. (2015). Analytical Study of the Extent of Practice and Implementation of Asei-Pdsi Approach by Teachers of

Baeten, M., Dochy, F., \& Struyven, K. (2012). Using Students' Motivational and Learning Profies in Investigating Their Perceptions and Achievement in Case-Based and Lecture-Based Learning Environments. Educational Studies, 38, 491-506.

doi:10.1080/03055698.2011.643113

Barry, K. \& King, L. (1995). Beginning Teaching: A Developmental Text for Effective Teaching (2 ${ }^{\text {nd }}$ ed.). Wentworth Falls, NSW: Social Science Press.

Beck, C., \& Kosnik, C. (2002). Components of a Good Practicum Placement: Student Teacher Perceptions. Teacher Education Quarterly, 29(2), 81-98.

Blanton, L.M., Berenson, S., \& Norwood, K.(2000) .Exploring a Pedagogy for the Supervision of Prospective Mathematics Teachers. Department of Mathematics, University of Massachusetts Dartmouth.

Brown, K. L. (2003). From Teacher-Centered to Learner-Centered Curriculum: Improving Learning in Diverse Classrooms. Education, 124, 49-54.

Cathcart, G.W.,Pothier, M. Y.,Vance, J. H., \& Bezuk, N. S. (2003). Learning Mathematics in Elementary and Middle Schools, Third Edition. Upper Saddle River, New Jersey Columbus, Ohio

Crick, R. D., \& McCombs, B. L. (2006). The Assessment of Learner-Centered Practices Surveys: An English Case Study. Educational Research and Evaluation, 12, 423-444. doi:10.1080/13803610600697021.

Hoben, N. (2006). Real Teachers, Real Classrooms and Real Experiences: The Work of Associates with Pre-service Teachers on Practicum. A Thesis Completed in Partial Fulfilment of the Requirements for the Degree of Doctor of Education, The University of Auckland, 2006.

Jones, M. G., \& Brader-Araje, L. (2002). The Impact of Constructivism of Education: Language discourse, and meaning. American communication Journal, Vol.5, Issue 3.

Jossey-Bass, Wilson, K., \& Fowler, J. (2005). Assessing the Impact of Learning Environments on Students' Approaches to Learning: Comparing Conventional and Action Learning Designs. Assessment \& Evaluation in Higher Education, 30, 87-101.

doi:10.1080/0260293042000251770

Kiggundu E., \& Nayimuli, S. (2009). Teaching Practice: A Make or Break Phase for Student Teachers. South African Journal of Education, EASA Vol 29: 345-358.

Marais, P., \& Meier, C. (2004). Hear Our Voices: Student Teacher's Experience during Practical Teaching. Africa Education Review, 1: 220-233.

Mathematics in Vihiga County, Kenya. American Research Journal of Mathematics. Original Article ISSN 2378-704X Volume 1, Issue 2. Moate, M. R., \& Cox ,A. J.,(2015) .Learner-Centred Pedagogy: Consideration for Application in a Didactic Course The Professional Counselor, 5(3), 379-389

Mvududu, N. H., \& Thiel-Burgess, J. (2012). Constructivism in Practice: The Case for English Language Learners. International Journal of Education, 4(3), 108-118. 
Mwangi, J. K., \& James, O. A. (2016). The Extent to Which Teachers of Mathematics and Chemistry Have Employed Use of ASEI and PDSI Approaches for SMASSE in Schools ; British Journal of Education, 4 (10), 15-21.Published by European Centre for Research Training and Development UK .

Ochongó, B. O. (2013). Implementation of ASEI-PDSI Approach in Mathematics Lessons in Nyamaiya Division, Nyamaira County, Kenya. Perry, R. (2004). Teaching Practice for Early Childhood. A Guide for Students. Available at http://www Routledge.com catalogues./0418114838.pdf.

Piaget, J. (1977). The Development of Thought: Equilibration of Cognitive Structures. (A. Rosin, Trans). New York: The Viking Press. Posamentier, A. S., Smith. B. S., \& Stepelman, J. (2006). Teaching Secondary Mathematics, Techniques and Enrichment Units, Pearson Prentice Hall Education.

Qazi, W., Rewat, J. K., \& Thomas, M. (2012). The Role of Practicum in Enhancing Student Teachers' Teaching Skills American Journal of Scientific Research, 44, 44-57.

Qiong, J. (2010). A Brief Study on the Implication of Constructivism Teaching Theory on Calssroom Teaching Reform in Basic Education. International Education Studies, 3, 2.

Roya, J. A., \& Hanieh, D. (2015). Review of Constructivism and Social Constructivism. Journal of Social Sciences, 1(1), 9-16.

Weimer, M. (2002). Learner-Centered Teaching: Five Key Changes to Practice. San Francisco, CA:

Wright, G. B. (2011). Student-Centered Learning in Higher Education. International Journal of Teaching and Learning in Higher Education, $23,92-97$ 